\title{
ADOLESCENT'S CONSTRUCTION OF PARENTAL VERBAL AGGRESSION: A QUALITATIVE STUDY ON RURAL FAMILIES COMMUNICATION IN INDONESIA
}

\author{
Berlianti Diana $^{1 *}$, Hubeis A.V. ${ }^{2}$, Hastuti Dwi ${ }^{3}$, Sarwoprasodjo Sarwititi ${ }^{2}$, Krisnatuti Diah ${ }^{3}$ \\ ${ }^{1}$ Bogor Agricultural University, Indonesia \\ ${ }^{2}$ Department of Science Communications, Bogor Agricultural University, Indonesia \\ ${ }^{3}$ Department of Family Science and Consumer, Bogor Agricultural University, Indonesia \\ *E-mail: diana.berlianti@gmail.com \\ ORCID: 0000-0002-6274-0288
}

\begin{abstract}
This article presented in-depth interviews on two focus group discussions about parental verbal aggression on 15 male and 15 female high school students in rural families in Indonesia. Parental verbal aggression is the most common and frequent aggression that happened to children in Indonesia, however, study about parental verbal aggression categories, frequency, painfulness degree, responses, and solutions from the adolescents perspective have rarely been done yet. Research shows that from nine categories of verbal aggression such as (a) put downs and shaming, (b) rejection, (c) blaming, (d) fault exaggerating, (e) threat, (f) invoking harm, (g) regret, (h) unfair comparison, (i) negative prediction, the most frequent verbal aggression to male adolescent was put downs and shaming. Parents usually said to their male adolescent words like "useless kid," "ungrateful child," "(acting) without considerations," "you are good for nothing" to make their children feel shame and shallow. The most frequent verbal aggression on female adolescent was, "if you're not going to help, just go!" and "you're good for nothing."
\end{abstract}

\section{KEY WORDS}

Verbal aggression, family communication, rural family, verbal aggression, rural adolescents, Indonesia.

The concept of verbal aggression or psychological abuse or emotional abuse is somewhat ambiguous. One of the arguments regarding verbal aggression or psychological abuse is the difficulty of proving harm to others without physical evidence (Morgan \& Wilson, 2005; Warburton \& Anderson, 2015). Verbal or psychological abuse usually came out as hurtful words, consequently, it is hard to see the physical trace. Even though hurtful words do not leave physical proofs, mounting evidence suggests that hurtful words or verbal aggression caused significant threats to children's emotional health (Claussen \& Crittenden, 1991; Springer et al., 2003; Moore \& Pepler, 2006; Loh, Calleja, \& Restubog, 2011; Odhayani, 2013). Children who experienced verbal aggression by their parents were discovered to be more physically aggressive, more antisocial, having more interpersonal problems, having substantially higher levels of anxiety, depression, somatization, anger-hostility than those who were not verbally violated (Vissing et al., 1991; Fry, McCoy and Swales, 2012, Tomoda et al., 2010). Verbal aggression created emotional problems in adolescents later development (Loh, Calleja, \& Restubog, 2011; Zoysa, Newcombe, \& Rajapakse, 2010; Moore \& Pepler, 2006; Deb \& Walsh, 2012) and distracting children's future development emotionally (Wright, Crawford, \& Del Castillo, 2009; Springer et al., 2006). Reports stated that children who verbally assault tends to have anxiety, depression, lack of emotional attachment and selfconfidence, low cognitive abilities, and social skills (Dube et al., 2002; Kjelsberg \& Dahl, 1999; Loh, Calleja \& Restubog, 2011). Verbal aggression alone without being accompanied by other forms of punishments contributed to decreasing children's self-esteem (Esteban, 2006; g 2008) and academic achievements (Solomon and Serres, 1999; Smith and Moore, 2013). Despite massive evidence of parental aggression effects, empirical studies have been rarely conducted on this topic (Loh, Calleja, \& Restubog, 2011; Moore, \& Peppler, 2006). 
Survey of Violence against Women and Children in Indonesia has shown that verbal aggression was the most common and most frequent form of assault. It is stated that almost two-thirds of the population in urban and rural experienced verbal aggression such as embarrassing and insulting the victims (Utami, 2013). Fathers and close relatives reported to be the assaulting actors in aggression towards children. It is very ironic considering Indonesia has already regulated children's protection. Law Number 23 Year 2002 on Child Protection mentioned that every child needs to get as broadest opportunities as possible to grow and develop optimally, be it in physical, mental or social domains and to have noble morals, and it is needed to conduct protective acts and to realize children's welfare by providing guarantees to fulfill their rights as well as to give indiscriminative treatment. Furthermore, family supposed to be the closest, the most intensive and the safest system (Couchennor,et al. 2004; Sanders, 1997; Hastuti, 2007) and should be able to provide love and protective function for children, however, many families have been found lacking to do so.

Verbal aggression is defined as "a verbal act that has the intent or perceived intent to symbolically hurt or threaten to hurt another" (Hyden, 1995; O'Leary, 2015). The act included "constant name-calling, harsh threats, and sarcastic comments that continually "beat down" the child's esteem with humiliation" (Loh, Calleja, \& Restubog, 2011). Verbal aggression often affected the way children see themselves compare with other forms of aggressions (Moore \& Peppler, 2006). Another definition is a communication process directed towards children with the intention of making them psychologically hurts. Those acts of communication can be active or passive, verbal or non-verbal (Solomon \& Serres 1999; Vissing et al., 1991). Vissing et al., (1991) stated that psychological aggression can be active, passive, verbal, and nonverbal. For example calling someone with bad names (active, verbal), slam the door (passive, nonverbal), stand silently and ignoring (passive, nonverbal). Verbal aggression is a term that can be used interchangeably with psychological or emotional abuse (Loh, Calleja, \& Restubog, 2011). Scholars tend to agree that verbal aggression usually involves psychological or emotional rejection through verbal or symbolic actions of aggressive behaviour (Zoysa et al., 2010). On the other hand, psychological abuse defined as a broad range of behaviours, including isolation, ostracism, and lack of attention (Claussen \& Crittenden, 1991). UNICEF (2012) illustrated emotional abuse as parental failure to provide a promotive environment for children's development. Children should get a decent and supportive environment and availability of attachment figures in order to be social-emotional competence developed in later life. "These acts must be reasonably within the control of the parent or person in a relationship of responsibility, trust, or power. Acts include restriction of movement, patterns of belittling, denigrating, scapegoating, threatening, scaring, discriminating, ridiculing or other non-physical forms of hostile or rejecting treatment (Krug, 2002). There are various definitions and terms of verbal aggression that can be very confusing, however, studies that exploring verbal aggression from the perspective of adolescents has been rarely conducted. This study aimed to explore parental verbal aggression construction from the perspectives of adolescents.

There are at least two scientific approaches in viewing verbal aggression. Some of them consider verbal aggression can be stand alone and different with other types of aggressions (Kinard, 2001; Lau et al., 2005). For example, Vissing et al., (1991) found a positive correlation between the incidents of verbal aggression with children's behavioral problems. She then concluded that verbal aggression can be separated from other types of aggression such as physical aggression (Vissing et al., 1991). On the other side, some researchers concluded verbal aggression cannot be separated from other types of aggression. According to those researchers, usually, one type of aggression followed by other types of aggression (Binggeli, Hart, \& Brassard, 2001; Brassard, Hart, \& Hardy, 2000). Scholars like Rohner and Rohner (1980), explained that parental or primary attachment figures reject their children both verbally and non-verbally. They argued that separating between verbal and nonverbal aggression then become an impossible task (Rohner \& Rohner, 1980). They also argued that both physical and verbal aggression happened at the same time and could lead to some developmental issues in children's future life. These academic argumentations indicate demands in parental verbal aggression toward adolescents studies. 
Some studies mentioned that gender became a determinant in parental verbal aggression. Past reports indicate that sons received physical aggression more than daughters while daughters accepted verbal aggression more than sons did (Galea, 2010; Idemudia \& Makhubela, 2011; Kitzmann, Gaylord, Holt, \& Kenny, 2003). Daughters were found to be more internalising such as angered while sons were more externalising like grieved in reacting with verbal aggression (Evans, Davies, \& DiLillo, 2008). It is very crucial to add gender as a consideration in verbal aggression studies.

Despite the fact that studies on parental aggression toward adolescents are limited, researchers have argued that adolescents are also at high risk for aggression (Loh, Calleja, \& Restubog, 2011). For instances, reports have found that events of parental verbal aggression toward adolescents were as prevalent as that of younger children (Solomon \& Serres, 1999; Vissing et al., 1991). However parental verbal aggression toward adolescent studies has been found scarce (Loh, Calleja, \& Restubog, 2011).

This research is also important to fill the lack of verbal aggression across the Asia. Studies of verbal aggression that is done in Asia is very scarce compared with similar studies in the western world (Kaplan et al., 1999; Schaefer, 1997; Vissing et al., 1991). Asia has different cultures with the western world. It is hypothetically safe to assume Asian has different perceptions and definitions of verbal aggression. Past studies mentioned that Indonesian parents would rather choose unavoidable disciplining tactics to their children such as giving fake promises, scare the child, yelled with a loud voice to their children, humiliate the child or compliment the child in front of others (For example Geertz, 1961; Zevalkink \& Riksen-Walraven, 2001). Studies stated that culture had a tremendous role in shaping the construction of verbal aggression (Zoysa et al. 2010; Loh, Calleja, \& Restubog, 2011). The cultural values in Indonesia that advancing manners, for instance, children should bow in front of the elder and kiss elder's hands, children has to refrain themselves to talk in front of the parents or parents patted their children's shoulder can be seen as an aggression in western world but those practices considered normal and a nonabusive ones in Indonesia and other parts of Asia such as Philipines (Geertz, 1985; Esteban, 2006; Loh, Calleja, \& Restubog, 2011). Furthermore, Sundanese and Javanese as the majority ethnics in this study have been posited parents especially fathers refer to a higher position for children. In those cultures, there is a cultural manner norm to put fathers as someone who possesses higher ranks, the senior ones, or elderly person according to the family tree that called awu (Suharti, 2004). If children wanted to interact with their fathers, they should use a proper language in accordance with undha usuk and unggah ungguh. Unggah ungguh is a set of gradual local language that has been used correspondingly with the cultural manner norms (Hidayat \& Pradanasiwi, 2012; Rochayanti, Pujiastuti, \& Warsiki, 2012; Soehardi, 1997; Soepardo, 2016). If adolescents failed to accomplish these manners, it will become a potential conflict that can be escalated to verbal aggression. Therefore, the aim of present study is to explore verbal aggression in Indonesia's cultural context.

An unresolved parent-adolescent conflict was found to be one of the sources of verbal aggression (Pagani et al., 2005). The report said that sources of parent-adolescent conflict were money problems, privilege, and household chores division (Pagani et al, 2005; Laursen, Coy, \& Collins, 1998). However, research that exploring the sources of verbal aggression has seldom been done.

This study used Parental Acceptance-Rejection (PAR) theoretically framework developed by Rohner and Rohner (1980) in order to understand verbal aggression conceptually. PAR is a parent to children (adolescent) socialisation theory that will be able to reflect parent-adolescent relation in a continuum. PAR will capture the degree of parental warmth on one side and coldness in another side (Rohner, Khaleque, \& Cournoyer, 2012). Parental warmth expressed by touching (such as hugs and kisses) and verbally saying (complimenting adolescent). On the other hand, parental rejection is represented by hostile behavior and insulting the adolescent. Parents do verbal aggression with the intention of hurting adolescents by using hurtful words that contain sarcasm, curses, yell, insults and humiliate the adolescents (Rohner, Khaleque, \& Cournoyer, 2012). PAR can predict the adolescent's function of the developmental outcome if they constantly received hurtful words 
from their parents. It is said that adolescents who were rejected by their parents will tend to be more hostile, aggressive, having low self-esteem and self-adequacy, emotionally unstable and having a bad worldview (Dube et al., 2002, Spillane-Grieco, 2000; Steely \& Rohner 2006); and having social withdrawal in adolescent social interactions (Chang et al., 2005).

There are some categories of parental hurtful words (Loh, Calleja, and Restubog, 2011) towards adolescents including words that contains put downs and shaming, rejection, blaming, fault exaggerating, threat, invoking harm, regret, unfair comparison, negative prediction. These constructs developed by Loh, Calleja, and Restubog (2011) will be used in the analysing content of hurtful words in current research. The categories of parental hurtful words are:

Words that contain put downs and shaming referred to phrases that embarrassing the adolescent's self-worth included "name calling," "foul language," "sarcastic remarks," and "derogatory remarks." For example, being called "dummy," "fool," "rascal," and "You are a good for nothing" (Loh, Calleja, \& Restubog, 2011).

Words that contain rejection referred to words/phrase that expressing parental withdrawal from caring and affection. Those phrases included "I (Mum/Dad) don't love you," and "Go!" (Loh, Calleja, \& Restubog, 2011).

Blaming words reflect phrases that allege adolescent of being at fault or making them feeling guilty about something beyond their control. For instances, "You are the cause of our misfortune" or "I am like this because of you." (Loh, Calleja, \& Restubog, 2011).

Words that contain fault exaggerating are associated with the expression that blows out adolescent's faults or weaknesses. For example parental comments such as, "You are always a loser!" or "You will never accomplish anything." (Loh, Calleja, \& Restubog, 2011).

Threat words reflect parental phrases to physically harm, intimidate and to stop material support. Phrases include "I will hit you," "I will starve you to death," or "I will not send you to school anymore." (Loh, Calleja, \& Restubog, 2011).

Invoking harms words contain parental hostile and dangerous words or misfortune will come toward adolescents. Examples include: "I wish the lightning would strike you," "I wish you will be dead," or "I wish you burn in hell." (Loh, Calleja, \& Restubog, 2011).

Regret words reflect disappointment that something bad should have happened to adolescent. Phrases include: "I wish I had aborted you," "I should not have let you live," or "I should have killed you when you were a baby." (Loh, Calleja, \& Restubog, 2011).

Unfair comparisons contain parental unreasonably compare adolescents to themselves, siblings, or others. The unfair comparison will make adolescent feel they are incompetent or inadequate, such as," "Why can't you be like your sister?" "Your classmate is better than you," or "Our neighbour's child behaves better than you." (Loh, Calleja, \& Restubog, 2011).

Negative prediction phrases that predict adolescent's destructive outcomes. Phrases include "You won't go far," "You will not amount to anything," or "You will go to hell.".

Therefore, this present study will be exploring types of parental verbal aggression as well as frequency and most hurtful words toward adolescents. This research will also be exploring adolescent's reaction and solutions.

\section{METHODS OF RESEARCH}

Invitations to follow a focus group discussion had already been sent to several vocational schools in a rural area near Jakarta. A focus group discussion (FGD) is a suitable method for exploring and examining the construction of verbal aggression in participants as well as their reasons without interfering participants to conclude something into an agreement. FGD is an ideal approach to examine individual stories, experiences, the point of views, beliefs system, and concern. FGD method can become an ideal approach to delivered participants' thought in their own language and terms (Kitzinger, 1994; Flick, 2002).

We selected adolescents in schools that fit the requirements of having developmental issues as reported by their counsellors. Among the invited schools, one school agreed to facilitate a discussion among adolescents and researchers. We then selected adolescents based on counsellor's recommendation and socio-economic diversity. The range of age was 
between 15-17 years old. Fathers and mothers highest educational background were mostly graduated from high school. The families' income averages were in the span of 4-6 million rupiahs, as shown in Table 1 below.

Table 1 - Social economic background of participants

\begin{tabular}{ll}
\hline Socio-economic background & Mean \\
\hline Family income (in million Rupiahs) & $4-6$ \\
\hline Educational background (in years) & 11.75 \\
Fathers & 11.51 \\
Mothers & 46 \\
\hline Age (years old) & 40 \\
Fathers & \\
Mothers & 22 \\
\hline Ethnicity (number of participants) & 7 \\
Sundanese & 2 \\
Javanese & 1 \\
Bataknese & 1 \\
Minahasanese & \\
\hline
\end{tabular}

Five male and female participants have been recruited to get in-depth interviews. The in-depth interviews enacted an anonymity principle and guaranteed the confidentiality. The recruited in-depth participants answered questions regarding the causal of parental verbal aggression toward adolescents as well as frequency, the most hurtful words and solutions.

On the first phase, we asked FGD participants mentioned parental hurtful words, frequency, the most hurtful words, responses and solutions in their own words. The second phase, we employed qualitative content analysis in order to analyze words/phrases in FGD and in-depth interviews (Neundorf, 2002; Hsieh \& Shannon 2005). Content analysis is an analysis technique where written texts are broken down into meaningful units/categories using carefully design rules (Hsieh \& Shannon, 2005). We used categories that have been developed by Loh, Calleja, and Restubog (2011). This study adopted the qualitative content analysis that used guidance coding that started with theoretically relevant findings (Hsieh and Shannon, 2005; Mayring 2014). Researchers invited three master degree counselors to analyze the contents of participants' responses. Those responses have been put into nine hurtful words categories (Loh, Calleja, \& Restubog, 2011). All of the counselors agreed without hesitations to put those hurtful words into the categories. We explored reasons behind parental verbal aggression toward adolescents from adolescents' perspectives as well as their responses and solutions.

\section{RESULTS OF STUDY}

We presented categories, subcategories of parental hurtful words toward adolescents participants in Table 2.

Put downs and shaming, referred to phrases that embarrassing the adolescent's selfworth included "name calling," "foul language," "sarcastic remarks," and "derogatory remarks. Father's hurtful words toward their sons in this category were "Stupid!", "Anjing (in English: dog, referred to an animal that unclean, filthy, a remarks that showed disgusting feature)" "Devil!", "You're not caring," "You're good for nothing," "You're a human, right?," "Animal!", "You're an animal."

Hurtful words from mothers toward their sons in this category were "Stupid!", "Dummy", "you're good for nothing," "Lazy," "indifferent!", "Ungrateful child!", "living corpse!", "deceitful kid," "Fast eater, slow worker!" "(You are) Very rude!"

Hurtful words from fathers toward daughters in this category were: "Shame on you for cannot do something like this", while mother's hurtful words to their daughters were: "you are a dilly- dallier, always come home late at night!", "You never reply when needed," You're rude to your mother for not answering," "The only ability You have is eating," "Lazy!", "You're good for nothing." "You never produce anything." "You are very slow at everything!" "You never help!", "Rude daughter!" 
Rejection words referred to expressions of parental withdrawal from caring and affection. Hurtful words from fathers to their sons were: "just go!", "If you do that, I don't love you!","It doesn't matter if you're not here", "Whether or not you're here, it will not make any different". Hurtful words from mothers to their sons were "just go!", "just go and don't come back to this house again," "Don't ever dare to step in this house!", "I (mum) go or you (participant) go?" "You'd better go if you're rarely at home!"

Female participants did not receive this kind of rejection but they received rejections from mothers. "Just go, I don't want to see you. I have other children!" or "Sleep outside, don't come near the house!"

Blaming words reflect phrases that allege adolescents of being at fault or making them feeling guilty about something beyond their control. Father expressed blaming words towards their sons such as, "it all happened because of you! (in Indonesia: gara-gara kamu!)". Mother stated toward their sons, "You are the cause of these bad lucks..."

Blaming words from fathers toward their daughters were, "I am tired to take care of you but you never do anything's right," while mothers said to their daughter, "I would never ever trust you anymore," or "only reasons that come out from your mouth."

Hurtful words that contain fault exaggerating contain expression that blows out adolescent's faults or weaknesses. Father and mother exaggerating words towards their sons were "You will never accomplish anything," "You will never succeed."

"Look at your brother, if it is time to come home, he will come. unlike you, you will never accomplish anything, you cannot do anything except playing around." (Pram, 17 years old).

Threat words reflect parental phrases to physically harm, intimidate and to stop material support. Phrases from fathers toward their sons were, "I will hit you!", "I will never pay your school tuition anymore," "Fight me (Father) if you dare," "I (father) am strong enough to physically fight with you and your friend." Mothers threat words towards their sons were, "I will hit you!" and "I will starve you!"

Threat words from father towards their daughters were, "I will hit you," "I will if you still at home", while mother said to their daughters, "I will pinch you."

Invoking harm words contain parental hostile and dangerous words or misfortune will come toward adolescents. Fathers and mothers stated to their sons, "Just die, you'd better be dead." Fathers towards their daughters found to be never said invoking harm phrases, but mother stated towards daughters, "You will get doomed to failure because you lied to me."

Regret words reflect disappointment that something bad should have happened to adolescent. Father's phrase towards son was "If you're gone, I still have other sons," while mother said to their sons "You shouldn't have been born at the first place." Father never said regret words to their daughter, but mother said, "I wish that you had never been born."

Unfair comparisons contain parental unreasonably compare adolescents with their parents' younger self, siblings, friends or other. Father's unfair comparison to their sons was, "When I was at your age, I can do anything independently, unlike you," while mother stated to their sons, "Look at your kind and smart brother, unlike you."

Unfair comparison from fathers toward daughters was "look at your friend, she can cook well, why can't you do that?" "Compared with your sisters you are the naughtiest and the most stupid one."

Unfair comparison from mothers toward daughters was," You have to be more like your friend, she is kind and diligent. You are stupid and stubborn," "You are lazy, be like other women. Women have to take care of their family later. Let your brother be lazy, his future wife will take care of him later." "You have to be more like her, she can earn money at a young age, you can only eat," "When I was at your age, I can do all of that by myself."

Negative prediction phrases that predict adolescent's destructive outcomes. Father's phrases to their sons include, "You will not pass the exam!". Mother's negative prediction was, "You will not become anything significant in the later life." Female participants never received negative prediction phrases from fathers, but they accept it from mothers, "You will never succeed in later life." 
Table 2 - Parental hurtful words toward adolescents participants

\begin{tabular}{|c|c|c|c|c|}
\hline \multirow[t]{2}{*}{ Categories } & \multicolumn{4}{|l|}{ Parental hurtful words } \\
\hline & Fathers-Sons & Fathers-Daughter & Mothers-Sons & Mothers-Daughters \\
\hline $\begin{array}{l}\text { 1. Put downs } \\
\text { and shaming }\end{array}$ & $\begin{array}{l}\text { Stupid!" } \\
\text { "Anjing (in English: dog, } \\
\text { referred to an animal } \\
\text { that unclean, filthy, a } \\
\text { remarks that showed } \\
\text { disgusting feature). } \\
\text { "Devil!" } \\
\text { "You're not caring" } \\
\text { "You're good for } \\
\text { nothing," "You're a } \\
\text { human, right?," } \\
\text { "Animal!", "You're } \\
\text { animal." }\end{array}$ & $\begin{array}{l}\text { "Shame on you for } \\
\text { cannot do something } \\
\text { like this" }\end{array}$ & $\begin{array}{l}\text { "Stupid!", } \\
\text { "Dummy" } \\
\text { "You're good for } \\
\text { nothing" "Lazy" } \\
\text { "indifferent!" } \\
\text { "Ungrateful Child!" } \\
\text { "Living corpse!", } \\
\text { "deceitful kid" } \\
\text { "Fast eater, slow } \\
\text { worker!" "Very } \\
\text { rude!" }\end{array}$ & $\begin{array}{l}\text { "You are a dilly- dallier, always } \\
\text { come home late at night!" } \\
\text { "You never reply when needed" } \\
\text { "You're rude to your mother for } \\
\text { not answering" } \\
\text { "The only ability You have is } \\
\text { eating" } \\
\text { "Lazy!" } \\
\text { "You're good for nothing." "You } \\
\text { never produce anything" } \\
\text { "You are very slow at everything!" } \\
\text { "You never help!" } \\
\text { "Rude daughter!" }\end{array}$ \\
\hline $\begin{array}{l}\text { 2. Rejection } \\
\text { words }\end{array}$ & $\begin{array}{l}\text { "Just go!" } \\
\text { "If you do that, I don't } \\
\text { love you!" } \\
\text { "It doesn't matter if } \\
\text { you're not here" } \\
\text { "Whether or not you're } \\
\text { here, it will not make } \\
\text { any different" }\end{array}$ & - & $\begin{array}{l}\text { "Just go!" } \\
\text { "Just go and don't } \\
\text { come back to this } \\
\text { house again" } \\
\text { "Don't ever dare } \\
\text { to step in this } \\
\text { house!" } \\
\text { "I (mum) go or you } \\
\text { (participant) go?" } \\
\text { "You'd better go if } \\
\text { you're rarely at } \\
\text { home!" }\end{array}$ & $\begin{array}{l}\text { "Just go, I don't want to see you. I } \\
\text { have other children!" "Sleep } \\
\text { outside, don't come near the } \\
\text { house!" }\end{array}$ \\
\hline $\begin{array}{l}\text { 3. Blaming } \\
\text { words }\end{array}$ & $\begin{array}{l}\text { "It all happened } \\
\text { because of you! (in } \\
\text { Indonesia: gara-gara } \\
\text { kamu!)" }\end{array}$ & $\begin{array}{l}\text { "I am tired to take } \\
\text { care of you but you } \\
\text { never do anything's } \\
\text { right }\end{array}$ & $\begin{array}{l}\text { "You are the } \\
\text { cause of these } \\
\text { bad lucks...." }\end{array}$ & $\begin{array}{l}\text { "I would never ever trust you } \\
\text { anymore," } \\
\text { "Only reasons that come out from } \\
\text { your mouth." }\end{array}$ \\
\hline $\begin{array}{l}\text { 4. Fault } \\
\text { exaggerating }\end{array}$ & $\begin{array}{l}\text { "You will never } \\
\text { accomplish anything," }\end{array}$ & & $\begin{array}{l}\text { "You will never } \\
\text { accomplish } \\
\text { anything," }\end{array}$ & \\
\hline 5. Threat words & $\begin{array}{l}\text { "I will hit you!", "I will } \\
\text { never pay your school } \\
\text { tuition anymore," "Fight } \\
\text { me (Father) if you dare," } \\
\text { "I (father) am strong } \\
\text { enough to physically } \\
\text { fight with you and your } \\
\text { friend." }\end{array}$ & $\begin{array}{l}\text { I will hit you," "I will if } \\
\text { you still at home" }\end{array}$ & $\begin{array}{l}\text { "I will hit you!" "I } \\
\text { will starve you!" }\end{array}$ & "I will pinch you." \\
\hline $\begin{array}{l}\text { 6. Invoking harm } \\
\text { words }\end{array}$ & $\begin{array}{l}\text { "Just die, you'd better } \\
\text { be dead." }\end{array}$ & - & $\begin{array}{l}\text { "Just die, you'd } \\
\text { better be dead." }\end{array}$ & $\begin{array}{l}\text { "You will get doomed to failure } \\
\text { because you lied to me." }\end{array}$ \\
\hline 7. Regret words & $\begin{array}{l}\text { "If you're gone, I still } \\
\text { have other sons," }\end{array}$ & - & $\begin{array}{l}\text { "You should not } \\
\text { have been born in } \\
\text { the first place." }\end{array}$ & "I wish you had never been born." \\
\hline $\begin{array}{l}\text { 8. Unfair } \\
\text { comparisson }\end{array}$ & $\begin{array}{l}\text { "When I was at your } \\
\text { age, I can do anything } \\
\text { independently, unlike } \\
\text { you," }\end{array}$ & $\begin{array}{l}\text { "Look at your friend, } \\
\text { she can cook well, } \\
\text { why can't you do } \\
\text { that?" "Compared } \\
\text { with your sisters you } \\
\text { are the naughtiest } \\
\text { and the most stupid } \\
\text { one." }\end{array}$ & $\begin{array}{l}\text { "Look at your kind } \\
\text { and smart brother, } \\
\text { unlike you." }\end{array}$ & $\begin{array}{l}\text { "You have to be more like your } \\
\text { friend, She is kind and diligent. } \\
\text { You are stupid and stubborn" } \\
\text { "You are lazy, be like other } \\
\text { women. Women have to take care } \\
\text { of their family later. Let your } \\
\text { brother be lazy, his future wife will } \\
\text { take care of him later" } \\
\text { "You have to be more like her, } \\
\text { she can earn money at a young } \\
\text { age, you can only eat" "When I } \\
\text { was at your age, I can do all of } \\
\text { that by myself." }\end{array}$ \\
\hline $\begin{array}{l}\text { 9. Negative } \\
\text { prediction } \\
\text { phrases }\end{array}$ & $\begin{array}{l}\text { "You will never pass the } \\
\text { exam!". }\end{array}$ & - & $\begin{array}{l}\text { "You will not } \\
\text { become anything } \\
\text { significant in the } \\
\text { later life." }\end{array}$ & $\begin{array}{l}\text { "You will never succeed in later } \\
\text { life." }\end{array}$ \\
\hline
\end{tabular}

We found that fathers rarely spoke hurtful words towards daughters compared to mothers. Female participants mentioned that their father seldom talked with them verbally. "Father rarely spoke, mum is very chatty,..." (Restu, 16 years old) 
Male participants received 24 hurtful words from father and 26 from mothers, while female adolescent got 4 hurtful words from father and 21 from mothers. Male adolescent received more hurtful words than female adolescents.

The most frequent hurtful words both from fathers and mothers towards male participants was in put downs and shaming category. Phrases such as, "you're good for nothing!", "You're not paying enough attention", "useless kid", "ungrateful child", "acting without consideration," were the most frequent words.

"Every day, my mother and father wake me up. They grumbled and said, "you're good for nothing, lazy head, you're an unhelpful child." (Senna, 17 years old)

"You never think of your mother who has already worked from dawn till night, you are very stubborn never obey your parents" (Seno, 16 years old)

"My parents have a scheduled of anger. I got scolded three times daily. First, when I get up in the morning, they said, "Lazy, you're good for nothing, all you do is just sleeping." When I come home from school, they yell at me, "you are a dilly-dallier, never paying attention, always come home late at night." Third, I got scolded again for whatever random reasons, sometimes, if I don't want to help house chores, my mother yelled, "You eat plenty of foods but always lazy to help, you're really good for nothing." (Soni, 16 years old).

"When I (father) was your age, your grandfather died, so, I have to do everything by myself. I was very independent, I can wash my own clothes and cook my own dishes unlike you who cannot do anything yet." (Felix, 16 years old).

Table 3 - The most frequent parental hurtful word

\begin{tabular}{lll}
\hline \multicolumn{1}{c}{ Male Adolescents } & Female Adolescents \\
\hline Fathers & You're good for nothing! & - \\
& You never pay attention! & \\
& Unhelpful kid & \\
& Ungrateful kid! & \\
& You're acting without consideration! & \\
\hline Mothers & $\begin{array}{l}\text { You're good for nothing! } \\
\text { Unhelpful kid }\end{array}$ & If you don't want to listen, just go! You're good for nothing! \\
& $\begin{array}{l}\text { Ungrateful kid! } \\
\text { You're acting without consideration! }\end{array}$ \\
\hline
\end{tabular}

The most frequent hurtful words from mother towards daughters were, "If you won't listen, just go" (rejection words) and "you're good for nothing" (put downs and shaming words). Female adolescents in this study reported that fathers did not say hurtful words often.

"My father seldom talks to me, it is different with my mother, she talks a lot. She says, "You're good for nothing, you always refuse to do house chores." (Cherry, 16 years old).

"My mother says "if you won't listen, if you don't want to obey me, just go." (Restu, 15 years old).

"Mum said, "If you don't want to help, you're good for nothing just go. I still have other kids to help me." (Adel, 16 years old).

Male adolescent stated that father's most hurtful words were "If I (father) ever lose you (sons), it does not matter because I still have other sons" (rejection phrase), "I (father) am strong enough to physically fight with you and your friend" (threat words). "Ungrateful child" (put down and shaming phrase), "You're human, right?" (put downs and shaming phrase). Mother's hurtful words towards son were, "go!" (rejection words), "You are a perfidious kid" (put downs and shaming), "You'd better die!" (negative prediction), "ungrateful child" (put downs and shaming), "you're human, right?" (put downs and shaming).

"I have three brothers, when I got home late at night, my father was angry and yelled, "If I ever lose you, it does not matter because I still have other sons." (Ronald, 15 years old)

"My mother told me, "You'd better be dead." Is it hurtful? No, it isn't, it's more than hurtful, I want to just die instead." (Sopyan, 15 years old).

"Every time I come home late, my mother gives me choices, "I'll go or you'll go?" but, instead of going, both of us stand still in the room. One day I go for real. When I decided to go back home, I got scolded, "If you want to run away from our house, I will not provide your 
tuition anymore." Since then, I never run away again, I want to have a brighter future. What will happen if I don't go to school, I will never be graduated? I don't want to eat rubbish later." (Rasyid, 16 years old).

"The most hurtful words are "Just Go!" (Raden, 16 years old).

Words that contain comparison were also found in some cases.

"When your brother was in high school, he was fine. He never came home late after school. You make trouble every time. All you do is just playing around." (Sopyan, 16 years old).

Other words were in put downs and shaming category.

"I would say that the most hurtful words I've ever received from my father were, "You're human, right?" (Aldi 17 years old)

"When I was a little boy, I got hit a lot, If my mother hit me the stove in our house can be flown somewhere else, but it was not as hurtful as being told that I was a perfidious kid" (Senna, 15 years old).

Some participants could not choose the most hurtful parental action. Some said getting hit by their parents were the most hurtful, some said the other way around.

"When I was a little till eight graders, I got pinched, hit and spanked a lot, but now as I am older my parents rarely did those physical violent actions toward me, but they said hurtful words often. If I compare which one is more hurtful now. l'd say hurtful words are more hurtful as the pain stays forever." (Pram, 17 years old).

"I'm not sure which one is more hurtful, having hurtful words or getting hit. Both of them are hurting me. Sometimes I got hit and scolded with hurtful words at the same time." (Rashid, 16 years old).

Aldi, 17 years old remembered that one time his father made an exaggerating challenge towards their sons and his friends.

"For me, the most hurtful words were when my father said, "You obviously challenge me, right? Bring your friends here, I still can fight you and your friends at the same time. I am strong enough to fight with you all," You can imagine how I felt Ma'am. I don't want to fight my own Father, Ma'am."

Female participants said that the most hurtful words from fathers were, "Go!" and "Let's see if you still live in this house." The most hurtful words from mother were "Go! Sleep outside the house," "You're good for nothing," and "Look at your kind friend,..."

"When I was a seventh grader, my mother made me left the house. I actually went to my friend's house. Her mother asked me to go home at 9 pm. I didn't know where to go. There was a river near my friend's house, I thought of jumping there instead. An old man stopped me and said, "Why do you look puzzled young girl?" I told him my story. He said to me to just forget what my mother said and just go home. "They will for sure look for you," he said. It was true for not only my family, my neighbor and my churchgoers went to look for me." (Ressa, 16 years old).

"When I came home late, my mother won't open the door for me. She had already prepared a suit for me to change outside. She yelled from my house," You sleep outside, change your clothes outside." (Sonya, 17 years old).

Table 4 - The most hurtful words according to participants

\begin{tabular}{|c|c|c|}
\hline & Male participants & Female participants \\
\hline Fathers & $\begin{array}{l}\text { "I ever lose you, it does not matter because I still have other sons." } \\
\text { "Your friends here, I still can fight you and your friends at the same time. } \\
\text { I am strong enough to fight with you all" } \\
\text { "Ungrateful kid" } \\
\text { "You're human, right?" }\end{array}$ & $\begin{array}{l}\text { "Go!" } \\
\text { "Let's see if you still live in } \\
\text { this house." }\end{array}$ \\
\hline Mothers & $\begin{array}{l}\text { "Go!" } \\
\text { "Perfidious kid" } \\
\text { "You'd better be dead" } \\
\text { "You're human, kight" }\end{array}$ & $\begin{array}{l}\text { "Go!" } \\
\text { "Sleep outside the house" } \\
\text { "You're good for nothing" } \\
\text { "Look at your kind friend..." }\end{array}$ \\
\hline
\end{tabular}


The Sources of Parent-Adolescent Conflict that Caused Parental Hurtful Words. Male adolescents mentioned that the cause of conflict were coming home late at night, rarely been at home, always playing around, never studying, refusing to do shalat (praying in Islamic tradition), refusing to do house chores, disobedient toward parents.

"My father said, you always play around at night doing nothing and never studying, what will you do when you grow up? We also knew that what we do was good for nothing, but we still need to associate with our peers." (Jordi, 16 years old).

"My mum says: "It is impossible for me to wake you up. You are just like a living dead corpse. All you do just playing around, you're lazy. Even asking you to do salat is a hard thing, I cannot ask you to do house chores. You're only good at eating." (Sopyan, 15 years old).

The source of verbal aggression for female adolescents was almost the same with the male did but female adolescent did not receive parental hurtful words for never studying and rarely shalat. Female adolescents also mentioned financial problems and social media interaction as the sources of conflicts.

"The bottom line is I would never ever trust you in money management! I gave a lot already and you still spend it carelessly." (Della, 16 years old).

"Mother, father, and brother yelled and cast me out of the house. When I was a seventh grader, my brother found me chat with my American online friend. My brother who knows English more thoroughly thought that my online friend had asked something inappropriate (porn) so he told my parents about it. My parents said if I kept continuing on doing that I will be cast out from the house." (Santi, 16 years old).

Jealousy over brothers. Adolescent participants mentioned that their parents often said hurtful words whenever they did not help house chores. Female adolescents highlight that even their brother did house chores, the quantity, and the type are quite different. Parents tend to differentiate the type and quantity of house chores.

"If we ever protested about our house chores division with my brother, my mother yelled, "He doesn't have to learn much about house chores, his future wife will do that if he got married later." (Wendy 17 years old)

Night Hours. Male and female adolescents have a different rule of night hours. Some adolescents said they have to be at home right after school time is over.

"My mother said that I have to be at home at $6 \mathrm{pm}$, so I cannot play after school. I got off school at 4 pm and I have to spend 2 hours trip to my house in Depok. I go home by train. If I got home late my mother will be angry and she said harsh and hurtful words." (Reynold, 16 years old).

Some male participants have night hours more freely.

"I have to be at home at $10 \mathrm{pm}$. If I came later than that I will be cast out from home." (Aldi, 17 years old).

"Usually, we got home at $4 \mathrm{pm}$. We play guitar at school, then we go to our friend's house and we got home at 9 or 10 pm." (Alan, 16 years old).

"We've been told by our parents to come straight from school at 4 . If we follow it, what will we do at home? It's so boring at home. We need to socialise with friends. We also know that what we do is good for nothing, but we feel unwelcome at home. Home is a very scary place to be. We like being at school with our friends." (Jordi, 16 years old).

"What will we do at home? We, boys, never study at home. If we get home early, we play "line (social media app)" with our friends from school. It will be better if we hang around with them instead." (Senna, 16 years old).

"I also want to get home first then we come out after that, but my mother won't let me out if I had already come. My mother said that I should go to school tomorrow or that my friend's house is too far so I cannot visit him. It is impossible for me to hang around with friends once I get home. It is better to come home late after all." (Rafi, 17 years old).

Female participants have an earlier night hour compared to male.

"I have to be at home at $8 \mathrm{pm}$ the latest. If I cannot fulfill that my mother won't let me in." (Lia, 17 years old).

"I have to be at home before dawn. Mum gets angry easily because her daughter to be a dilly-dallier at night." (Mulya, 16 years old). 
Parental Hurtful Words and Adolescent Responses. When adolescents received parental hurtful words, they admitted that they have a mixed up feeling. They felt sad, afraid, angry and upset.

"It was obvious that I was very sad when I received hurtful words from my mum and Dad. I feel sad, angry, scared and upset at the same time." (Aldi, 17 years old).

Some adolescents stated that they felt helpless, not knowing what to do and felt good for nothing whenever their parents said harsh and hurtful words.

"Nothing seems right for my mum. Everything I do always seem wrong for her. That makes me sad." (Adel, 16 years old).

Reflective activity and silence are the best responses. The most common responses from adolescent were silent. Sometimes they talked back to their parents whenever they received hurtful words.

"I've been asked to answer and say something after I got scolded, but if I talked back, they said I was a brazen child, if I didn't answer then they said "you just pretend to not listening, right? Have you got any ears or mouth?” (Restu, 17 years old).

The silence was considered to be the best responses since it was impolite to talk back when adolescents got scolded by their parents. It was also implying that they realized their mistakes.

Adolescents also did reflective action if they accepted parental hurtful words. They sometimes realized that parental harsh and hurtful words usually came out from their inappropriate behavior.

"I don't think my parents condemn me. I don't know whether I should blame myself or my parents for their harsh words. I know that my mum and dad wanted the best for me, but I don't like the way they do. Why did my parent have to do it with harsh words and why I never did something exactly like they wanted me to do? It was very frustrating because I don't want to be like this..." (Raden, 17 years old).

What Parents Should Do According to Participants. Participants considered several ways to avoid parental verbal aggression. Among them were parent-adolescent two ways communication, "good parenting", keeping in mind about "the prophecy" of hurtful words, and comparing adolescent with the process of being not with the result.

Parent-adolescent two ways communication. Adolescent expressed that parents should open parent-adolescent communication, being equal and respect their children. If parents did those things, adolescent thought that they will able to discuss and overcome parentadolescent problems and conflicts.

"I, sometimes, asked my parents to discuss our problem instead of yelling at me and being harsh. My parents said I was pretending to be mature, smart and trying to over my parent." (Pram, 16 years old).

Adolescents thought that whenever they have problems, the problems should be resolved at a time. Talking about the same problems over and over again will only become a potential problem ahead.

"The past problems shouldn't be talked over and over again. It will become a very big problem if my mum or myself ever brought the problem back." (Lia, 15 years old).

"Good parenting". Participants felt that they received many negative words such as forbidden words and also imperative words (parental commands or instructions). Participants wanted to be treated as adults. They expected their parents to listen to their opinions. Participants thought if parents press their adolescents too much, adolescents will become rebellious later.

"I think parents should not be pressing their children at home. If they pressed the children too much, the children will become obedient at home and become rebellious outside." (Jordi, 16 years old).

Participants thought that parents should not yell or stomp their feet and hands when they communicate with their children. Participants felt that their parents have an authoritarian parenting. Participants have to obey their parent's commands or words. Participants stated that their parent's wish was unquestionable. Participants wanted parents to guide them more with a two-way discussion and dialogues instead of blaming or accusing them. 
Parents of female adolescents have some ways to discipline their children less violent when they found adolescents negative behaviour. For example, when one of adolescent came home late, parents will be taking "advantage" by seizing their gadgets or allowances.

Parents should be keeping in mind about "the prophecy" of hurtful words. Parents should remember that bad words can invite bad lucks. Adolescents encourage their parents to change their negative words with positive ones because bad words can sometimes become prophecy. Adolescents stated that they tended to oblige their parents if parents tried to be in their shoes. If parents said bad words all the time, adolescents were afraid that their words will shape their self -perception and became "self -prophecy."

"Parents should understand children's circumstances. They should give positive sentences. Parents cannot say something bad like "You're good for nothing," if they consistently said those bad words, what if I became a truly useless person." (Restu, 17 years old).

"Words are just like prayers. If my parents said that I was stupid, what if I became a real stupid one?" (Jordi 16 years old).

Participants thought that parental advice can become a solution. It can prevent parental hurtful words.

"I think it was better for my mum to give advice instead of cursing me" (Fira, 16 years old).

Aldi (17 years old) felt sad if his parent advises him wisely while he did contrarily.

"Mum said, "When I died, you will understand my advices are true." I feel bad to let my mother down and promise her to do the best. I really don't understand why I did (something bad) it again."

Parents should compare with the process of being not with the result. Participants did not like when parents compare them with their friends, neighbors, siblings, or with parents "younger self." According to adolescents, parents should empathize with their children condition. If parents want to compare them with others, they should compare them with somebody's hard work in order to get succeeded.

"If parents want to compare me with others, they should explain the process of being succeeded." (Risma, 17 years old).

\section{DISCUSSION OF RESULTS}

In this research, interviews were conducted with 15 male high students and 15 female high school students to explore types of parental verbal aggression as well as frequency and most hurtful words toward adolescents in Indonesia. This study will also be exploring adolescent's reaction and solutions. Our exploratory results indicated that many of the categories in the present study duplicated Loh, Calleja, and Restubog's (2011) classification of parental verbal abuse.

It is implied that parental verbal abuse in many countries of the world, including Indonesia, may have relatively similar meaning. Nonetheless, alertness should be taken in light of the different cultural values regarding parent-child relationship and child rearing practices in Indonesia.

Our present study can show hurtful words from father-son, father-daughter, mother-son, and mother-daughter from a number of hurtful words. Male participants received 24 hurtful words from fathers while female received only 4 hurtful words. At the same time, male participants received 26 hurtful words from mothers, while female participants got 21 hurtful words from mothers.

Overall, male participants received more hurtful words both from father and mother. Male participants received hurtful words in every category from mother and father, at the same time, female participants accepted all categories of hurtful words except for the categories of negative predictions (Table 2). Previous studies mentioned that Fathers tend to be more engaged with their sons, have less contact with daughters (Lewis and Lamb, 2003; Lamb, 2010; Lamb \& Lewis, 2010). Consequently, higher interactions between fathers and male adolescents made hurtful words easier to be said from fathers to their male adolescents. 
During the time, male and female adolescents consistently report being closer to their mother than fathers (Lewis and Lamb 2003). Findings of this study suggested that female participants gained more hurtful words from mothers than from father. Only four categories of hurtful words came from father while almost all categories of hurtful words delivered by mothers.

Generally, male participants received more hurtful words compared with female participants, both from mother and father. Theoretically on a daily basis, mothers were more involved in children's monitoring and more intense in term of giving active supervision than fathers did (Lamb 1987). Due to the fact that mothers had more intense supervision, unsurprisingly, this study provide findings that mothers said hurtful words to male and female participants more often than fathers did. Moreover, other studies found that adolescent saw fathers as a distant figure. Previous knowledge found the reason why fathers have been seen as distant figures. Firstly, adolescent found playing with their fathers is irrelevant and a little embarrassing. Secondly, men are associated in a number of cultures with disciplinary functions, for example, Korean daughters saw fathers as distant and controlling (Lewis and Lamb, 2003; Shwalb, Nakazawa, Yamamoto, \& Hyun, 2010). Previous studies detected that culturally, parents in Indonesia had rather chosen unavoidable discipline's tactic, such as giving fake promises, scare the child, scold severely, embarrass the child in front of another child (e.g. Geertz, 1961; Zevalkink and Riksen-Walraven, 2001). Despite the lack of studies in Indonesia that mentioned how father and mother differed in parenting, reports from across the Asia mentioned that one of the values of fathering came from The Confucian value that was "Strict Father, kind mother" (Shwalb, Nakazawa, Yamamoto, \& Hyun, 2010).

Sundanese and Javanese are the majority ethnicities of informants in this study. In Sundanese as well as Javanese, parents especially fathers refer to a higher position for children. In those cultures, there is a cultural manner norm to put father as someone who possesses higher ranks, the senior ones, or elderly person according to the family tree that called awu (Suharti 2004). If children wanted to interact with their father, they should use a proper language in accordance with unggah ungguh and undha usuk (Hidayat \& Pradanasiwi, 2012). Unggah ungguh is a set of gradual local language that has been used correspondingly with the cultural manner norms. While undha usuk refers to the variations of languages that is used for certain peoples. Undha usuk determines which vocabularies and level of language as well as proper behaviour should we choose in accordance with a certain people that we interact with (Hidayat \& Pradanasiwi, 2012; Rochayanti, Pujiastuti, \& Warsiki, 2012; Soehardi, 1997; Soepardo, 2016). Findings that stated fathers rarely spoke with their adolescents might be the result of the cultural manner norms for both Sundanese or Javanese. Female participants stated that their fathers had rarely spoken with them and fathers were associated with quiet and distant figures.

Moreover, previous studies stated that parents who adopt harsh parenting toward their children will make their children feel rejected (Khaleque and Rohner 2012a; Khaleque and Rohner, 2012b; Anonas and Alampay, 2015; Peterson and Bush, 2013). Adolescents who feel rejected by their parents will form distance upon them (Khaleque and Rohner 2012a; Khaleque and Rohner, 2012b; Anonas and Alampay, 2015; Peterson and Bush, 2013). This present study supports those findings. It is implied that adolescents who received parental hurtful words reported having a distant figure from their fathers. Participants reported having a one way of communication with their parents. Parents reported having an authoritarian way of parenting. Authoritarian parenting may also result from a parent-adolescent social distance (Peterson and Bush, 2013).

Islam is the majority of participants' religion in this study. In Asian Muslim families parents have the obligation to transmit Islamic value to their offsprings in order to get a sense of morality and reinforce family ties (Franceschelli and O'Brien, 2014), however, on daily basis, parents have to be alert on the differences of parent-adolescent culture in order to prevent parental harmful words. For example, when parents wanted to make their adolescents offspring to do shalat (praying), they cannot ask the way they asked younger children, but they have to raise their adolescent's awareness first by cultivating their spirituality beforehand (Canales, 2009). It is also interesting to spot on the finding of the current research that only male participants found to be dejected to do praying, while female 
participants did not report the same. This finding consistent with King and Roeser (2009) that stated female adolescents were found to be more religious than the male adolescents.

Participants stated that parental hurtful words often arose whenever they arrived at home later than the designated curfew, absenting from home, lazy studying, refusing to do shalat, dejected from doing housework chores, and ignoring their parent's orders. Female adolescents added the jealousy over the arrangements of house chores that benefitting their brothers as one of the common causes of conflict. The findings supported the study that stated the causes of parent-adolescent conflicts usually come from the division of house chores, money, and child privilege (Pagani et al., 2005). Findings supplemented absenting from home, barely study, refusing to pray, ignoring parent's order, arriving later than the arrangements as the most common causes of parent-adolescents conflict. In theory, conflicts could be seen as the opportunity to examine parents-adolescents expectations and renegotiating their roles and responsibilities (Laursen \& Collins, 2004; Littlejohn \& Domenici, 2006). Moderate amounts of conflict during adolescence have been associated with better adjustment than either no conflict or frequent conflict (Adams \& Laursen, 2001). Conflicts were a good vehicle in strengthening parents-adolescents communication. If families had the ability to answer the challenges, the communication pattern will be healthier and ready for next challenge (Laursen \& Collins, 2004). Previous research has shown that bickering and disagreements between parents and their children usually increase during adolescence. Theoretically, conflict, at moderate levels and within the context of supportive family relationships can transform family relationships to let the child more autonomy (Assadi, 2011).

This research strengthened a study that concluded fathers and mothers treated their sons and daughters differently. The reasons were because parents thought that boys should be given more autonomy than girls did. On that basis, boys could enhance their problemsolving skills and more explorative than girls did (Berns, 2004). Male participants in this study had been given more freedom of night hours than female participants did. This present study found, not only male participants received more hurtful words than female participants did, but also fathers of male participants often verbally confronted their sons by saying things such as "Fight me, If you dare." Prior studies can explain the reason behind that particular parental behaviour. It was said that parents expected their sons to be stronger, more coordinated and alert while girls expected to be more gentle and fragile (Berns, 2004).

Male participants stated that the most frequent hurtful words from father and mother were "you're good for nothing," "you're an ungrateful person," "You're acting without parental consideration," and "You're an unhelpful person." As for female participants hurtful words from mothers were "If you're not going to help, just go," and "you're good for nothing. Our result showed that put down and shaming was perceived by participants to be the most common type of parental verbal abuse in Indonesia. This finding was consistent with the same study in Phillippine (Loh, Calleja, Restubog, 2011). This study discovered that fathers rarely spoke hurtful words to their female adolescents. A stated before, female adolescent described their fathers as quiet figures that rarely been spoken. On the contrary, female participants explained mothers as "chatty figures".

Participants in this study reported being emotionally in pain by parents whenever they received hurtful words. The consequences included of feeling hopeless, all torn up and the feeling of wanting to "just" die instead of getting more hurtful words. These findings supported massive pieces of evidence that mention the effects of parental verbal abuse, including the tendency to have anxiety and depression (Dube et al., 2002; Kjelsberg \& Dahl, 1999; Loh, Calleja \& Restubog, 2011).

This study found that participants feel most welcomed and comfortable at school. They stated that school was more homey than their own homes. These findings consistent with other studies that declared adolescents were more attached with their peers compared to parents (Helgeson, 2010). Participants found that hurtful words sometimes happened because they have communication problems with their parents. According to participants, there were several ways to repair parents-adolescents communication such as making a twoway communication pattern, "good parenting", keeping in their minds about "the prophecy" of hurtful words, and comparing the adolescent's outcomes instead of their process. 
Parents, according to participants should remember that their bad words can become a somewhat of prophecy for their children future life. In Islamic perspectives, as a major belief of these informants, there is a belief that anything we said will become true. Therefore, parents should avoid giving hurtful words to their children as it will become "prophecies." Participants proposed a solution of changing negative words with positive ones. Participants also stated that if parents wanted to compare them with others, they wanted to compare with the process of being a success not only with their results.

\section{LIMITATIONS}

A number of limitations exist in this present study. First, the findings of the present study were only based on self-report from adolescents' perspective and there is no way to validate if any of hurtful words were indeed verbal aggression. Second, many studies mentioned about the bidirectionality concept of parent-adolescent verbal abuse (Pagani et al., 2005). Thus usually there is a reciprocal verbal abuse between parent-adolescent, however, the present study only focuses on parental verbal abuse. Third, although participants came from a private school, their families may have the same social economic status with most of the Indonesian. In term of socialising their children, social class played a significant role (Irwin and Elley, 2011). Future research may choose more variety participants.

\section{ACKNOWLEDGMENTS*}

First and above all, I praise God, the almighty for providing me this opportunity and granting me the capability to proceed successfully. This research appears in its current form due to the assistance and guidance of several people. I would therefore like to offer my sincere thanks to all of them. Prof. Aida Vitayala Hubeis, thanks for accepting me as a Ph.D student. I want to express my deep thanks to my esteemed co-promotor Dr. Dwi Hastuti, Dr. Sarwititi Sarwoprasodjo, \& Dr. Diah Krisnatuti, for the trust, the insightful discussion, offering valuable advice, for your support during the whole period of the study, and especially for your patience and guidance during the writing process. I cannot finish without thanking my family, I warmly thank and appreciate my parents and my mother and father-in-law for spiritual support in all aspects of my life. I want to express my gratitude and deepest appreciation to my lovely sweet daughter, Qonitan, and my two curios sons, Farabi and Samudera, for your great patience and understandings and for being always cheered for me whenever I am tired. And finally, My lovely Husband, Dear Agus, without your supports and encouragements, I could not have finished this work, it was you who kept the fundamental of our family, and I understand it was difficult for you, therefore, I can just say thanks for everything and may Allah give you all the best in return.

\section{REFERENCES}

1. Adams, R., \& Laursen, B. (2001). The organization and dynamics of adolescent conflict with parents and friends. Journal of Marriage \& the Family, 63, 97-110.

2. Anonas, M. R. L., \& Alampay, L. P. (2015). The Moderating Role of Parental Warmth on The relation between Verbal Punishment and Child Problem Behaviors For Same-sex and Cross-sex Parent-Child Groups. Phillip J Psychol, 48 (1): 115-152.

3. Assadi, S. M., Smetana, J., Shahmansouri, N., \& Mohammadi, M. (2011). Beliefs about parental authority, parenting styles, and parent-adolescentconflict among Iranian mothers of middle adolescents. International Journal of Behavioral Development, 35(5) 424-431.

4. Berns, R. (2004). Child, family, school, community: Socialization and support (6th Ed.). Belmont, CA: Thomson Delmar Learning.

5. Binggeli, N., Hart, S., \& Brassard, M. (2001). Psychological maltreatment of children. Thousand Oaks, CA: Sage. 
6. Brassard, M., Hart, S., \& Hardy, D. (2000). Psychological and emotional abuse of children. In R. Ammerman \& M. Hersen (Eds.), Case studies in family violence (2nd ed.). New York: Kluwer Academic/Plenum.

7. Canales, A. D. (2009). A noble quest: cultivating Christian spirituality in Catholic adolescents and the usefulness of 12 pastoral practices. International Journal of Children's Spirituality. Vol. 14, No. 1, 63-77.

8. Chang, L., Li, K. K., Lei, L., Liu, H., Guo, B., Wang, Y., \& Fung, K. Y. (2005). Peer acceptance and self-perceptions of verbal and behavioural aggression and social withdrawal. International Journal of Behavioral Development. 29: 48.

9. Claussen, A. H., \& Crittenden, P. M. (1991). Physical and psychological maltreatment: Relations among types of maltreatment. Child Abuse Negl. 15: 5-18.

10. Couchenor, D. (2004). Families schools and communities together for young children (2nd ed.). Belmont, CA: Thomson Delmar Learning.

11. Deb, S., \& Walsh, K. (2012). Impact of physical, psychological, and sexual violence on social adjustment of school children in India. School Psychology International, 33: 391.

12. Dube, S. R., Anda, R. F., Felitti, V. J., Edwards, V. J., \& Croft, J. B. (2002). Adverse childhood experiences and personal alcohol abuse as an adult. Addictive Behaviors, 27, 713-725.

13. Esteban, E. J. (2006). Parental verbal abuse: Culture-specific coping behavior of college students in the Philippines. Child Psychiatry and Human Development, 36, 243-259.

14. Evans, S. E., Davies, C., \& Di Lillo, D. (2008). Exposure to domestic violence: Metaanalysis of child and adolescent outcomes. Aggression and Violent Behavior, 2-27-2008. doi: 10.1016/j.avb.2008.02.005

15. Figer, R. C. (2008). Looking through the eyes of the child: The phenomenon of child verbal abuse in the Philippines. Relational Child and Youth Care Practice, 21I, 46-58.

16. Flick, U. (2002). An introduction to qualitative research. London: SAGE Publication.

17. Franceschelli, M., \& O'Brien, M. (2014). Islamic Capital' and Family Life: The Role of Islam in Parenting. Sociology, 1-17.

18. Fry, D., McCoy, A., \& Swales, D. (2012). The Consequences of Maltreatment on Children's Lives: A Systematic Review of Data From the East Asia and Pacific Region. Trauma Violence Abuse, 13: 209.

19. Galea, M. (2010). Does child maltreatment mediate family environment and psychological well-being? Psychology, 1, 143-150

20. Geertz, H. (1983). Keluarga Jawa [Javanese Family]. Jakarta: Grafitti Press.

21. Hastuti, D. (2015). Pengasuhan: Teori and Prinsip serta Aplikasinya di Indonesia [Parenting: Theories, Principles, Applications In Indonesia]. Bogor: IPB Press.

22. Helgeson, V. S. (2012). Psychology of Gender Fourth Edition. New Jersey: Pearson Education Inc.

23. Hidayat, A., \& Pradanasiwi, G. S. (2012). Hubungan tingkat pendidikan formal orangtua dengan unggah-ungguh bahasa jawa peserta didik smp negeri 2 kaliwiro kabupaten wonosobo [The relationship between parental formal education with javanese language unggah-ungguh in middle school 2 kaliwiro, wonosobo district. Jurnal Pendidikan, Bahasa, Sastra, and Budaya Jawa_Universitas Muhammadiyah Purworejo, Vol. 01 / No. 01.

24. Hsieh, H. F., \& Shannon, S.E. (2005). Three approaches to qualitative content analysis. Qualitative Health Research, 15(9), 1277-1288.

25. Hsieh, H. F., Shannon, S.E. (2005). Three approaches to qualitative content analysis. Qualitative Health Research, Vol. 15, No. 9, 1277-1288.

26. Hyden, M. (1995). Verbal aggression as prehistory of woman battering. Journal of Family Violence, 10, 55-71.

27. Idemudia, E., Makhubela. (2011). Gender Difference, Exposure to Domestic Violence and Adolescents'Identity Development. Gender \& Behaviour, 9(1).

28. Irwin, S., \& Elley, S. (2011). Concerted Cultivation? Parenting Values, Education and Class Diversity. Sociology, 45: 480. 
29. Kaplan, S. J., Pelcovitz, D., \& Labruna, V. (1999). Child and adolescent abuse and neglect research: A review of the past 10 years. Part I: Physical and emotional abuse and neglect. Journal of the American Academy of Child and Adolescent Psychiatry, 38, 12141242.

30. Khaleque, A., \& Rohner, R. P. (2012a). Pancultural associations between perceived parental acceptance-rejection and psychological adjustment of children and adults: A meta-analytic review of worldwide research. Journal of Cross-Cultural Psychology, 43, 784-800.

31. Khaleque, A., \& Rohner, R. P. (2012b). Transnational relations between perceived parental acceptance-rejection and personality dispositions of children and adults: A metaanalytic review of worldwide research. Personality and Social Psychology Review, 16, 103-115.

32. Kinard, E. (2001). Characteristics of maltreatment experience and academic functioning among maltreated children. Violence and Victims, 16, 323-337.

33. King, P. E., \& Roeser, R. W. (). Religion and Spirituality in Adolescent Development. In Lerner, R. M., \& Steinberg, L. (Eds.), Handbook of Adolescent Psychology. Hoboken, NJ: John Wiley and Sons.

34. Kitzinger, J. (1994). The methodology of focus groups: The importance of interaction between research participants. Sociology of Health \& Illness, Vol. 16, No. 1.

35. Kitzmann, K. M., Gaylord, N. K., Holt, A.R., Kenny, E. D. (2003). Child witnesses to domestic violence: A meta-analytic review. Journal of Consulting and Clinical Psychology,Vol. 71, No. 2, 339-352.

36. Kjelsberg, E., \& Dahl, A. A. (1999). A long term follow-up study of adolescent psychiatric in-patients. Part II. Predictors of delinquency. Acta Psychiatrica Scandinavica, 99, 237242.

37. Krug, E. G. (2002). Child Maltreatment: Prevalence, Incidence and Consequences in the East Asia and Pacific Region: A Systematic Review of Research Strengthening Child Protection Systems Series: No 1. Retrieved from UNICEF East Asia and Pacific Regional Office (EAPRO): https://www.unicef.org/eapro/Child_Maltreatment.pdf

38. Lamb, M. E. (2010). How do fathers influence children's development? Let me count the ways. In M. E. Lamb (Ed.), The role of the father in child development (5th ed.) (pp. 1-26). Hoboken, NJ US: John Wiley \& Sons Inc.

39. Lamb, M. E., \& Lewis, C. (2010). The development and significance of father-child relationships in two-parent families. In M. E. Lamb (Ed.), The role of the father in child development (5th ed.) (pp. 94-153). Hoboken, NJ US: John Wiley \& Sons Inc.

40. Lau, A., Leeb, R., English, D., Graham, J., Briggs, E., Brody, K., et al. (2005). What's in a name: A comparison of methods for classifying predominant type of maltreatment. Child Abuse \& Neglect, 29, 533-551.

41. Laursen, B., \& Collins, W. A. (2004). Parent-Child Communication During Adolescence. In Vangelisti A. L. (Ed.). Handbook of Family Communication. Mahwah, New Jersey: Lawrence Erlbaum.

42. Laursen, B., Coy, K. C., \& Collins, B. A. (1998). Reconsidering Changes in Parent-Child Conflict across Adolescence: A Meta-Analysis. Child Dev, 69(3): 817-832.

43. Lewis, C., Lamb, M. E. (2003). Fathers' Influences on children's development: The evidence from two-parent family. European Journal of Psychology of Education. Vol XVIII no 2, 211-228.

44. Littlejohn, S. W., \& Domenici, K. (2007). Communication, Conflict and The Management of Difference. Long Grove, IL: Waveland Press Inc.

45. Loh, J., Calleja, F., Restubog, S. L. D. (2011). Words that hurt: A qualitative study of parental verbal abuse in the philipines. J Interpers Violence, 26: 2244.

46. Mayring, P. (2014). Qualitative content analysis. Theoretical foundation, basic procedures and software solution. Austria. Retrieved October 28, 2016, from websites: www.beltz.de

47. Moore, T. E, \& Peppler, D. J. (2006).WoundingWords: Maternal Verbal Aggression and Children's Adjustment. Journal of Family Violence (C _ 2006). doi: 10.1007/s10896-0059007-x. 
48. Moore, T. E., \& Pepler, D. J. (2006). Wounding words: Maternal verbal aggression and Children's Adjustment. Journal of Family Violence (C _ 2006). doi: 10.1007/s10896-0059007-x

49. Morgan, W. M., \& Wilson, S. R. (2005). Nonphysical child abuse: A review of literature and challenge to Communication scholars. In P. Kalbfleisch (Ed.), Communication yearbook 29 (p. 1-33). Mahwah, NJ: Lawrence Erlbaum.

50. Neuendorf, K.A. (2002). The Content Analysis Guidebook. Thousand Oaks, CA: Sage Publications.

51. O'Leary, K. D. (2015). Psychological abuse: A variable deserving critical attention in domestic abuse. In Maiuro, R. (Ed.), Perspectives on verbal and psychological abuse. New York: Springer Publishing Company. Retrieved from googlebooks: https://books.google.co.id/books? isbn=0826194672.

52. Odhayani, A. A. (2013). Behavioural consequences of child abuse. Canadian Family Physician, Vol. 59, 8831-836.

53. Pagani, L.S., Tremblay, R. E., Nagin, D., Zoccolillo, M., Vitaro, F., McDuff, P. (2005). Risk factor models for adolescent verbal and physical aggression toward mothers. International Journal of Behavioral Development, 28 (6), 528-537.

54. Peterson, G. W., \& Bush, K. R. (2013). Conceptualizing culltural influences on socialization: Comparing parent-adolescent relationship in the united States and mexico. In Peterson, G. W., \& Bush, K. R (Eds.), Handbook of Marriage and The Family Third Edition. New York, NY: Springer.

55. Rochayanti, C., Pujiastuti, E., \& Warsiki, A. Y. N. (2012). Sosialisasi budaya lokal dalam keluarga jawa [Socialization of local culture in javanese family]. Jurnal IImu Komunikasi, Vol. 10, No. 3, pp. 308-320.

56. Rohner, R. P., \& Rohner, E. C. (1980). Antecedents and consequences of parental rejection: A theory of emotional abuse. Child Abuse and Neglect, 4, 189-198.

57. Rohner, R. P, Khaleque, A., \& Cournoyer, D. E. (2012). Introduction to parental acceptance-rejection theory, methods, evidence, and implications. Retrieved June 22, 2016 from the University of Connecticut Center for the Study of Interpersonal Acceptance and Rejection website at www.csiar.uconn.edu.

58. Sanders, M. R. (1997). Every parent a positive approach to chlidren's behavior. Boston: Addison-Wesley.

59. Schaefer, C. (1997). Defining verbal abuse of children: A survey. Psychological Reports, $80,626$.

60. Shwalb, D. W., Nakazawa, J., Yamamoto, T., \& Hyun, J. H. (2010). Fathering in Japan, China, and Korea: Changing contexts, images, and roles. In M. E. Lamb (Ed.), The role of the father in child development (5th edition) (pp. 341-387). New York: Wiley.

61. Smith, D. E., \& Moore, T. M. (2013). Family Violence and Aggression and Their Associations With Psychosocial Functioning in Jamaican Adolescents. Journal of Family Issues, 34: 745.

62. Soehardi. (1997). Pengembangan Tata Krama dalam Rangka Pembinaan Budaya [Manner development in term of elevate culture]. Humaniora, Vol: VI.

63. Solomon, C. R., \& Serres, F. (1999). Effects of parental verbal expression on children's self-esteem and school marks. Child Abuse and Neglect, 23, 339-351.

64. Spillane-Grieco, E. (2000). From parent verbal abuse to teenage physical aggression. Child and Adolescent Social Work Journal, 17, 411-430.

65. Springer, K. W., Sheridan, J., Kuo, D., \& Carnes, M. (2003). The Long-term Health Outcomes of Childhood Abuse An Overview and a Call to Action. J Gen Intern Med, Vol. 18, 18:864-870.

66. Steely, A. C., \& Rohner, R. P. (2006). Relations Among Corporal Punishment, Perceived Parental Acceptance, and Psychological Adjustment in Jamaican Youths. Cross-Cultural Research. 40: 268.

67. Suharti. (2004). Pendidikan sopan santun and kaitannya dengan perilaku berbahasa jawa mahasiswa [Manner education and its relation with student's behavior of speaking]. Diksi, Vol 11, No. 1. 
68. Supardo, S. (2016). Perubahan repertoire dalam tata krama bahasa jawa [Repertoire changes in javanese language mannerism]. Cakrawala Pendidikan. No. 3, Year: XIV.

69. Tomoda, A., Sheu, Y. S., Rabi, K., Suzuki, H., Navalta, C. P., Polcari, A., \& Teicher, M. H. (2010). Exposure to parental verbal abuse is associated with increased gray matter volume in superior temporal gyrus. Neurolmage, 54, S280-S286.

70. Utami, D. R. W. W. (2013). Violence Against Women Survey in Indonesia. Workshop on Improving the integration of gender perspective into Official Status. Central Bureau of Statistics republic Indonesia. Retrieved from website: unstats.un.org

71. Vissing, Y. M., Straus, M. A., Gelles, R. J., \& Harrop, J. W. 1991. Verbal aggression by parents and psychosocial problems of children. Child Abuse and Neglect, 15, 223-238.

72. Warburton, W. A., \& Anderson, C. A., (2015). Aggression, Social Psychology of. In Wright, J. D. (Ed.), International Encyclopedia of the Social \& Behavioral Sciences, 2nd edition, Vol. 1. Netherlands: Elsevier Ltd.

73. Wright, M. O., Crawford, E., \& Del Castillo, D. 2009. Childhood emotional maltreatment and later psychological distress among college students: The mediating role of maladaptive schemas. Child Abuse and Neglect, 33, 59-68.

74. Zevalkink, J., Riksen-Walraven, J. M. (2001). Parenting in Indonesia: Inter- and intracultural differences in mothers' interactions with their young Children. International Journal of Behavioral Development, 25: 167.

75. Zoysa, P. D., Newcombe, P. A., Rajapakse, L. (2010). Outcomes of parental use of psychological aggression on children: A structural model from Sri Lanka. Journal of Interpersonal Violence, 25(8) 1542-1560. 